\title{
Rekonsiliasi Epistemologi Antara Agama dengan Sains (Telaah tentang Pemikiran Filsafat Seyyed Hossein Nasr)
}

\author{
Ali Maksum \\ Dosen IAIN Sunan Ampel Surabaya
}

Epistemologi, dalam paradigm sains, sebenarnya merupakan cabang filsafat yang secara khusus diminati semenjak abad ke-17 M. Namun, ketika memasuki paroh abad ke 20 ini, epistemologi telah mengalami perkembangan pesat dan begitu beragam ke arah berbagai jurusan. Sebab utamanya adalah tumbuhnya cabang-cabang ilmu pengetahuan secara terus menerus tanpa henti. ${ }^{1}$

Sebagai ciri khas yang patut mendapat perhatian dalam perkembangan epistemologi pada masá modern adalah munculnya pandangan baru mengenai pengetahuan. Pandangan itu dikemukakan oleh Prancis Bacon (I 561-1626) bahwa pengetahuan manusia; Human knowledge adalah Human Power. ${ }^{2}$ Pengetahuan baru berarti dan berguna apabila dapat memberi nilai positif manusia dalam penguasaan atas alam. Sebagai akibatnya, ilmu pengetahuan selama masa modern sangat mempengaruhi dan mengubah pandangan manusia dan dunianya. 
Sementara itu, abad modern adalah zaman ketika manusia menemukan dirinya-sebagai kekuatan yang dapat menyelesaikan persoalan-persoalan hidupnya. Penemuan metode ilmiah yang berwatak empiris dan rasional ${ }^{3}$ secara menakjubkan membawa kemajuan ilmu pengetahuan dan teknologi yang luar biasa. Industri dan berbagai macam penemuan ilmu pengetahuan membawa kemudahan-kemudahan hidup, membuka wawasan kehidupan banu, dan melahirkan pola pemikiran banu, yang disebut modernisme. Modernisme ditandai dengan rasionalisme, kemajuan, dan sekularisme. ${ }^{4}$ Bersamaan dengan itu, pengetahuan yang tidak didasarkan pada ukuran-ukuran ilmiah dan nilainilai religius tidak mendapatkan apresiasi yang memadai.

Modernisme akhimya dirasakan membawa kehampaan dan ketidakbermaknaan. ${ }^{5}$ Timbul berbagai kritik dan usaha pencarian baru. Manusia membutuhkan pola pemikiran baru yang diharapkan membawa kesadaran dan pola kehidupan baru. Kritik terhadap modernisme dan upaya pencarian ini sering disebut pascamodernisme atau postmodemisme.

Krisis epistemologi yang mendasari paradigma sains modem, mengundang sejumlah pemikir kontemporer untuk memberikan alternatif pemecahannya. Gregory Bateston, misalnya, melihat secara mendasar permasalahan yang ditimbulkan dari perkembangan ilmu pengetahuan dan teknologi modern. Menurutnya, sebab utama yang menimbulkan krisis modernisme adalah kesalahan epistemologi yang mendasariilmu pengetahuan dan teknologi modern. ${ }^{6}$

Beberapa ciri dari epistemologi modern yang dianggap menjadi penyebab timbulnya krisis di atas, dapat ditelusuri dari unsur-unsunnya : pertamas dilihat dari tujuan pengetahuan adalahuntuk diterapkan. Ini adalah akibat dari pengaruh pemikiran Bacon yang menegaskan bahwailmu pengetahuan banu dianggap bermakna apabila meningkatkan kekuasaan manusia, baik atas alam maupun sesama.' Dengan demikian, sains harus bernilai praktis bagi manusia, diantaranya dalam bentuk teknologi. Akibatnya penaklukan alam dan mengeksploitasinya habis-habisan tidaklah dapat dianggap sebagai kesalahan.

Kedua, dilihat dari metode yang digunakan adalah deduktif-induktif 
atau logico-bypotetico-verifikatif, sebagai akibat pengaruh pemikiran positivisme. Métode ini amat dominan dalam epistemologi modern, khususnya dalam metode keilmuan.

Ketiga, objek yang dikaji adalah realitas empiris inderawi, dan dapat dipikirkan oleh rasio. Dalam perspektif ini, budaya yang dihasilkan epistemologi di atas adalah budaya inderawi, yaitu budaya empiris, duniawi, sekuler, humanistik, utiliter, dan hedonistik. ${ }^{9}$

Selain Batestos, masih terdapat tokohilmuwan yang mengajukan kritik senada terhadap epistemologi modern. Mereka adalah Marx Horkheimer, Whitehead, Thomas Kuhn, Paul Feyerabend, Ian Miroff, T. Roszak, J.R. Ravets, Theodore W. Ardono, dan Eric Fromm. Kritik mereka terarah kepada masyarakat yang merupakan hasil perkembangan ilmu-ilmu alam dan salah satu akibatnya ialah bahwa manusia modern semakin terasing (aliniated) dari dirinya sendiri, dari lingkungan sosialnya, dan bahkan dari Tuhannya.

Dalam hubungannya dengan persoalan di atas, dikalangan Muslim, lahirpula pemikir alternatif, sebagai pemikir besar Islam kontemporer, Seyyed Hossein Nasr. la adalah seorang profesor dalam bidang sains, filsafat, sufisme dan ahli dalam ilmu-ilmu keislaman lainnya dari The George Washington University, Amerika Serikat.

Setidak-tidaknya sebagai eksposisi kritiknya terhadap Barat modern secara terinci dan sistematis, ia menulis buku yang menyangkut topik : Man and Nature: The Spiritual Crisis of Modem Man, Islam and the Plight of Modern Man, Knowiledge and the Sacred, dan Traditional Islam in the Modern World.

Lewat karya-karyanya dan dalam posisi serta kapasitasnya yang ada, Nasr mengembangkan gerakannya yang disebutnya sendiri dengan "Tradisionalisme Islam" (TI). Dengan gerakan TI ini seolah Nasr tampil sebagai juru bicara baik kepada masyarakat Barat maupun masyarakat Timur. Kepada Barat ia menyarankan pemikiran Islam, yang ia tawarkan sebagai alternatif nilai (value) dan way of life, sementara kepada dunia Timur ia memberitahukan bahwa Barat tengah mengalami kebangkrutan spiritual, yang menurut penilaiannya tidak cukup dipahami oleh dunia Timur. Sehingga Nasr menyarankan agar Timur menjadikan Barat sebagai case study, guna mengambil hikmah dan pelajaran, sehingga Timur tidak mengulangi kesalahan-kesalahan Barat. ${ }^{10}$ 


\section{Seyyed Hossein Nasr: Sebuah Biografi Singkat}

Seyyed Hossein Nasr lahir pada 7 April 1933 di kota Teheran, Iran, negara tempat lahirnya para sufi, filosof, ilmuwan, dan penyair muslim terkemuka. Ayahnya, Seyyed Valiullah Nasr, disamping terkenal sebagai ulama, juga sebagai dokter dan pendidik pada masa berkuasanya dinasti Qajar. Kemudian pada masa pemerintahan dinasti Reza shah, ia diangkat setingkat dengan jabatan Menteri Pendidikan. ${ }^{\text {.1 }}$

Nasr dapat dikatakan sebagai sosok agak tipikal cendekiawan Muslim yang dibesarkan dalam dua tradisi; Islam "tradisional" dan Barat "modern". Seperti diakuinya sendiri ia sebenarnya hidup dalam tension (ketegangan) yang kontinyu. la berasal dari keluarga ulama dan dibesarkan dalam tradisi dan locus ulamaSyi'ah tradisional yang mencakup nama-nama beser seperti Thabathabs'i, Hazbini, dan Mutahhari. Selanjutnya ia memperoleh pendidikan Barat modern melalui dua lembaga tinggi yang termasuk terkemuka di Amerika; Massachussetts Institute of Technology (MIT) dan Harvard University.

Seperti diketahui, pada awalnyza, Nasr mendapatkan pendidikan dacannya di Teheran, kemudian ia hijrah ke Qum untukbelajar filsafat, ilmu kalam, dan tasawuf pada sejumlah ulama besar Syi'ah di sana. Selanjutnya, Nasr mendaftarkan diri ke MIT mengambil bidang fisika dan matematika teoritis di bawah bimbingan filosof modem terkenal, Betrand Russel (m. 1970). Di perguruan tinggi ini, ia mendapat gelar B.Sc dan MA. Belum puas dengan keahlian yang dimiliki, ia melanjutkan program $\mathrm{Ph}$.Dnya(S-3) di Universitas Harvard. Di sini, ia menekuni bidang Filsafat dan Sejarah Sains (Philosophy and Histony of Science), dengan spesialisasi pada Islamic Science and Phylosophy. ${ }^{22}$ Ketika di Harvand, la belajar Sejarah dan Pemikiran Islam pada orientalis terkenal HAR. Gibb; Sejarah Sains pada George Sarton; dan pada Harry Walfson dalam Sejarah Teologi dan Filsafat. ${ }^{13}$

Selama belajar di Barat, Nasr juga terlibat aktif dalam gerakan counter culture yang terjadi disana. Yaitu sebuahgerakan pemikiran yang mengkritik peradaban modern Barat yang mulai dilanda kekeringan nilai, moral, dan spiritual. Disamping itu, Nasr juga mengadakan kontak dengan para pemikir 
keagamaan, seperti A.K. Comarswamy, Rene Guenon, dan Fritjof Schuon. Salah satu gagasan penting mereka adalah apa yang disebut filsafat perennial, yaitu pemikiman kefilsafatan yang menyangkut metafisika universal. Perennialisme, nantinya, menjadi salah satu tema terpenting dalam gerakan pembaruan Nasr.

Setelah memperoleh gelar Ph.D dalam sejarah Sains dan filsafat Islam pada 1958, Nasr kembali ke Iran. Selama di Iran, ia diangkat sebagai guru besar di Universitas Teheran. Di lembaga ini, Nasr juga sempat menjadi dekan Fakultas Sastera selama 1968-1972 dan membantu rektor 1970-1971. Sebelum itu, pada tahun 1962-1965, Nasr diangkat sebagai profesor tamu pada Harvard University.

Pada masa kekuasaan Shah Pahlevi, Nasr termasuk pendiri Akademi Filsafat Iran (Iranian Imperial Acaderry of Philosophy); dan ia diangkat sebagai presiden pertama lembaga ilmiah ini pada 1975 -1979. ${ }^{14}$ Selain itu, ia bersama Ayatullah Murtadha Muthahhari (1919-1979) dan Ali syari'ati (1933-1977), dan beberapa tokoh lain, pada akhir 1965 mendirikan Husainizyab Irshad, lembaga yang bertujuan mengembangkan ideologi Islam untuk generasi muda berdasarkan perspektifSyi'ah. Tetapi menjelang ditutupnya lembaga tersebut oleh rejim Shah pada 1973, Nasr dan Muthahhari keluar dari lembaga ini, yang menurut mereka telah dikuasai oleh Ali Syari'ati. Menurut penilaian kedua tokoh ini, Syari'ati telah menyalahgunakan lembaga ini untuk ambisi politiknya. Nasr sangat kritis dengan Syari'ati yang dipandangnya keliru menampilkan Islam sebagai agama revolusioner dengan mengorbankan aspek spiritualnya. Menurut Nasr, Syari'ati adalah seorang modernis muslim yang menciptakan semacam liberation theology di dunia Islam karena pengaruh westernisme dan Marxisme. Bagi Syari'ati, "Shi'isme was religion for protest"15 Dalam penilaian Nasr, gagasan Syari' ati sangat berbahaya.

Konflik antara Nasr dengan Syari'ati lebih disebabkan karena perbedaan pendekatan dalam upaya memperbaiki nasib Iran untuk masa depan. Nasr mendekatinya dari sudut perkembangan rohaniah karena pengaruh sufisme, sehingga Nasr tidak keberatan "dekat" dengan penguasa Iran - yang dalam penilaian kelompok revolusioner dianggap bobrok, tiran, dan sewenang wenang. Yang diinginkan Nasr dalam menyembuhkan kebobrokan moral 
penguasa Iran dan krisis manusia modern adalah dengan membangun basis metafisis-religius yang dapat menyingkirkan pandangan dunia materialisme penguasa Pahlevi pemimpin Iran sebelum revolusi - Nasr dibenci oleh kelompok penentang shah.

Sementara Syari'ati dan kelompok revolusi lainnya, seperti Ayatullah Khomaeni melihatnya dari kaca mata sosiologis, sehingga cenderung memilih jalan kekerasan dan memimpin massa dalam setiap aksi yang muncul. Gerakan revolusi yang diarsiteki Khomaeni dan Syari'ati ini, berhasil menumbangkan rejim Shah dan mendirikan Republik Islam Iran (RII) tahun 1979 hingga sekarang.

Namun sebelum revolusi meletus, Nasr berada dalam posisi genting dan terancam, makanya ia memutuskan untuk hijmah ke Amerika dan tidak akan kembali ke Iran. Walaupun ia hijrah ke Amerika dalam upaya menyelamatkan diridari kekacauan politik di negerinya, namun reputasinya sebagai ilmuwantidak menurun, ${ }^{16}$ dan langsungditerima di Temple University sebagai profesor dalam kajian pemikiran Islam.

Pada tahun 1985, Nasr mengakhiri tugasnya di Temple University untuk selanjutnya hijrah ke George Washington University juga sebagai guru besar pemikiran Islam sampai sekarang. Dua tahun kemudian ia menerbitkan bukunya yang berjudul Tradition Islam in the Modern World (1987).

Sewaktu Fazlurrahman dan Isma'il Raji al-Faruqi masih hidup, Nasr dan kedua pernikir ini dijuluki sebagai tiga intelektual Muslim paling terkemuka di AS sejak dekade 70an. Ketika tahun 1988, Harfford Seminary Foundation mengadakan konferensi tentang kaum Muslim di AS, untuk aspek intelektualnya, ketiga orang inilah yang dibahas.

Selain mengajar, Nasr juga aktif memberikan ceramah dan kuliah di tiga kawasan: Asia, Eropa, dan Amerika di seputar pemikiran Islam dan problem manusia modern. Disamping itu, ia juga rajin menulis buku, artikel dan monogmaf. Dari tahun 1958 sampai sekarang tidak kurang dari 55 judul buku dan 450 dalam bentuk artikel dan monograf sudah diterbitkan dan dipublikasikan ke berbagai negara. 


\section{PEMIKIRAN EPISTEMOLOGI NASR}

Istilah epistimology pertama kali digunakan oleh J.F. Ferrier dalam karyanya Institute of Methaphysics, dimana ia membagi filasafat menjadi dua cabang; metafisika dan epistemologi. ${ }^{17}$ Epistemologi atau filsafat/teori pengetahuan adalah cabang filsafat yang mempelajari dan mencoba menentukan kodrat dan skope pengetahuan, sumber, metodologi, dan dasarnya, serta pertanggung jawaban atas pernyataan mengenai pengetahuan yang dimiliki.

Perkembangan epistemologi modern dapat ditelusuri dan ditemukan dalam pemikiran filsafat Francis Bacon. Karena Baconlah yang dianggap sebagai perintis metode induktif dan sistematisasi prosedur ilmiah. Menurut Russel, dasar filsafat Bacon sepenuhnya bersifat praktis, yaitu unutuk memberikan kekuasaan kepada manusia atas alam penyelidikan ilmiah. ${ }^{18}$ Dengan menolak transendensi filsafat, Bacon menjaditokoh empirismedan positivisme. Dengan pendekatan ini, ia menolak secara tegas filsafat dan metafisika tradisional yang masih menggunakan metode kontemplatif dan intuitif karena tidak menambah sesuatu pun pada kemampuan manusia untuk menguasai dunia dan alam.

Kemudian dalam beberapa dekade terakhir ini, epistemologi mengalami perkembangan baru, yang ditandai perkembangan besar terhadap sejarah sains, serta peranan yang dimainkan sejarah sains dalam mendapatkan dan mengkontruksikan wajah ilmu pengetahuan dan kegiatan ilmiah yang sesungguhnya terjadi perkembangan baru itu dinamakan "pemberontakan terhadap positivisme ". Tokoh-tokoh epistemologi baru ini antara lain: Thomas Kuhn, Paul Feyerabend, N.R. Hanson, Robert Palter, dan masih banyak lagi. ${ }^{19}$

Dalam pada itu telah muncul pemikiran paling mutakhir yang menyoroti unsur-unsur pokok epistemologi modern dari perspektif keagamaan (tradisional) yang dikembangkan Nasr. Ia mencoba melakukan rekonsiliasi epistemologi antara agama dan sains setelah terjadinya "perceraian" diantara keduanya sejak renaisans di Eropa. Dalam sejarahnya sains modern berkembang ditandai dengan pelepasan dari doktrin agama, akibatnya sains modern menjadi benar-benar sekuler: 


\section{a. pemikiran tentang realitas.}

Kritik pertama Nasr, berkaitan dengan pemahaman terhadap realitas, sains modern memandang bahwa realitas adalah segala sesuatu yang bersifat empiris, profan dan tak bermakna spiritual. Konsepsi ilmiah tentang alam dan pandangan dunia reduksionis dan materialistik, menurut Nasr ilmu peengetahuan modern mengabaikan, meremehkan atau menyangkal segala aspek metafisik, spiritual, kualitatif dan estetis alam. Alam, hanya dipandang sebatassumber bagi kekuatan dirinya dan ekspresi dari akalnya sendiri. Sikap manusia terhadap alam adalah lebih cenderung untuk menaklukkan dan menghancurkan. Manusia modern melakukan alam sebagai seorang pelacur, meraup kepuasan sebanyak-banyaknya tanpa ada rasa tanggung jawab. Akibat kedangkalan sains modern yang tidak bendasarkan cahaya ketuhanan itu, menyebabkan terjadinya berbagai krisis seperti krisis ekologi, polusi udara dan air, menipisnya ozon, dan terutama krisistentang kemanusiaan sendiri.

Berbeda dengan sudut pandangan sains modern tersebut, Nasr menyatakan bahwa Islam memandang realitas bersumber dari kalimat tauhid La ilaba illa Allah. Makna terdalam dari kalimat tersebut adalah tidak ada wujud (realitas) selain wujud Tuhan. Menurut Nasr, realitas lain selain Tuhan tidak lain hanyalah cermin dari sekian banyak "keberadaan Ilahiah" (al-Hadharat al-Ilabizyah). Realitas dalam Islam, kata Nasr, dapat dikelompokkan ke dalam lima keberadaan (al-Hadharat al-Ilabizyjah al-Khamsab)untuk menggambarkan hierarki seluruh Realitas dalam urutan menurun : (1) Keberadaan hakekat Ilahiah, esensi Tuhan (babut); (2)Keberadaan nama dan sifat Tuhan (Labut); (3) keberadaan malaikat (jabarut); (4) keberadaan psikis dan b. manifestasi halus, di sebut juga dunia perantara (malakut); dan (5) keberadaan fana atau dunia fisikal (nasut).20

Keberadaan hakekat Ilahi, menurut Nasr, adalah wujud yang tidak dapat dikenal dan tidak dapat dijangkau oleh apa pun, kecuali Tuhan sendiri. Oleh karena itu, Absolut Murni. ${ }^{21}$ Nama Tuhan tidak dikenal di dunia ini, kemudian Tuhan menyebutkan Nama dan sifat-sifat Tuhan untuk dikenal. Maka secara emanasi, lahirlah apa yang disebut labut. Labut dapat dipersamakan dengan prinsip kreatif atau wujud. Yaitu prinsip ontologis dari keseluruhan kosmos, 
dan karena itu merupakan yang absolut terhadap seluruh ciptaan. Agar dapat sampai ke dunia, diciptakanlah dunia malaikat (jabarut), yaitu realitas dimana ketentuan-ketentuan dasar (archetype) diciptakan. Sedangkan malakut, sebagai mediator antara Tuhan dengan dunia psikis manusia. Malakut adalah keberadaan substansi jiwa atau yang sering disebut intellec. Nasut adalah keberadaan alam fisik, ia merupakan manifestasi yang paling akhir, ia juga merupakan lambang ketuhanan. Oleh karena itu disebut ayat. Dengan demikian, ia bukan sekedar materi, melainkan memiliki makna. Hierarki keberadaan itulah yang disebut manifestasi Tuhan(tajalliyat). ${ }^{22}$

Pandangan tentang realitas seperti di atas, membuat manusia tradisional melihat citra Ilahi dalam bayangannya sendiri. la memahami bahwa dirinya adalah citra manusia yang berasal dari sumber Ilahiyah.

\section{b. Tauhid : Landasan Transendensi}

Doktrin taubid adalah formulasi metafisikal yang paling mendalam, mempunyai aspekdantingkat pengertian. Ptrtama, adalah penekanan $\mathrm{pad} a$ karakter kesementaraan dan ketakabsolutan segala sesuatu yang bersifat makhluk berarti diciptakan dan tidak permanen. Kedua, adalah penekanan bahwa ada "sesuatu yang lain" di luar dunia ini yang merupakan Realitas Tertinggi yang meliputi segala realitas.

Mengikuti terminologi Al-Qur'an, Nasr mengemukakan empat kualitas dunia tertinggi, yaitu awal dan akhir, dhazir dan batin. ${ }^{23}$ Tuhan disebut Awal berarti seluruh realitas berasal dari-Nya, ${ }^{24}$ dan Tuhan sebagai $A$ khir berarti semua realitas akan kembali kepada-Nya. Dengan kata lain la adalah asal sekaligus tujuan. Sedang Tuhan sebagai Zhabirdan Bathin berarti Tuhan adalah realitas Yang mencakup segalanya, Yang meliputi dan Yang merangkum. ${ }^{25}$

Kosmos terdiri atas berbagai tingkat realitas, tidak hanya Yang fisik, tetapi ia membentuk suatu kesatuan karena ia mesti memanifestasikan ketunggalan sumber dan asal-usul metafisiknya (di dalam agama disebut Tuhan). ${ }^{26}$

Anatomi kosmos Islam ini, dalam berbagai derajat dan tingkatannya, 
membentang ke bawah dari yang tertinggi hingga yang terendah, atau dapat dilihat membentang ke atas dari yang terendah hingga yang tertinggi, didasarkan dari keterangan wahyu Islam sendiri. Pikiran muslim yang menerima pandangan tentang kosmos seperti itu, mau menerima wahyu sebagai sumber pengetahuan yang tertinggi. Prinsip ini, pada hakekatnya menyangkut kesatuan dan gradasi sesuatu, yaitu secara metafisik, realitas adalah satu dan tidak banyak, tetapi secara kosmologis, dunia nyata hanyalah satu dari keadaan wujud yang banyak.

Dalam alam raya yang hierarkis ini, kehidupan manusia berlangsung. Wahyu bukan hanya kunci untuk memahami alam raya, tetapi juga alat yang penting bagi manusia untuk menempuh perjalanan dari tingkat eksistensi yang lebih rendah sampai ketingkat yang paling tinggi, yaitu "kehadiran Ilahiah". Perjalanan ini tidak lain adalah kehidupan manusia itu sendiri. ${ }^{2 J}$

\section{c. Metodologis Sains}

Dari segi metodologi, sains modern diciptakan dengan menggunakan satu metodologi saja, yaitu apa yang dikenal dengan sebutan "metode ilmiah". Ketunggalan metode ini, melahirkan gagasan bahwa hanya ada satu jenis sains tentang alam yang mungkin ada. Pandangan itu mengimplikasikan bahwa derajat kreativitas ilmiah dan kemurnian pemikiran diukur oleh tingkat penerapan "metode ilmiah" sebagai alat ukur bagi masyarakat ilmiah. Dari sini, Nasr juga mengkritik faham rasionalisme Descartes yang mengatakan bahwa kebenaran sesuatu boleh diyakini kalau sesuai dengan kriteria yang dirumuskan oleh rasio. Dalil "Cogito ergo sum" (saya berpikir maka saya ada) dinilai oleh Nasr sebagai metode kaca mata kuda Yang terlalu mengagungkan rasio dan cenderung menafikan keberadaan manusia lebih utuh sebagai totalitas Yang bereksistensi.

Pengetahuan yang hanya dihasilkan oleh kesadaran psikis (bukan spiritual) dan rasio hanyalah bersifat terbagi-bagi dan sementara. Pengetahuan yang akan dapat membawa kebahagiaan dan kedamaian, hanyalah akan dapat dimih bila seseorarig telah membuka mata hatinya, atau visi intellectus-nya, ${ }^{28} \mathrm{lalu}$ 
senantiasa melakukan pendakian rohani ke arah titik pusat lewat hikmah spiritual agama.

- Sedang dalam Islam, menurut Nasr, para ilmuwan Muslim menggunakan metode yang majemuk dalam menciptakan elemen sains, sesuai dengan makna dan subjek dari term sains yang dikaji. Para ilmuwan muslim, telah menggunakan setiap jalan pengetahuan yang terbuka bagi manusia, dari kontemplatif-intuitif, rasionalisasi, interpretasi kitab suci, hingga observasi dan eksperimentasi. ${ }^{29}$

Dari sejarah intelektual Islam, dijumpai sejumlah besar literatur yang membahas persoalan metodologi pengetahuan. Semua madzab intelektual yang beragam dalam Islam seperti madzab-madzab dalam ilmu kalam dan filsafat: masyai'yah (peripatetik), Isyraqiyah (illuminasi), dan teosofi transendental (al hikmah al-mutta'aliyah), demikian pula madzab-madzab dalam ma'rifah (gnosis), yang kerap dikaitkan dengan para sufi, telah menyentuh persoalan yang sama, tetapi dari perspektif yang berbeda. ${ }^{30}$

Selanjutnya Nasr, menunjukkan karakteristik metodologi sains Islam : (1) level pertama membicarakan tentang persoalan manusia yang merupakan kutub "subjektif" pengetahuan, yaitu subjek yang mengetahui. Kutub ini terdiri dari semua fakultas dan kekuatan untuk mengetahui yang ada pada manusia. (2) Level kedua baru berbicara soal alam semesta, yang merupakan kutub "obyektif" pengetahuan, yaitu objek yang diketahui. Peran yang dimainkan metodologi pengetahuan berkaitan dengan hubungan esensial antara hirarki fakultas pengetahuan manusia dengan hirarki alam semesta, dan dengan prinsip-prinsip yang mengatur itu.

\section{d. Hirarki Sains}

Dari buku-bukunya tentang sains, nampaknya Nasr membagi sains secara umum ke dalam dua kelompok : Sains metafisika dan sains partikular. Sains metafisika merupakan sains yang paling universal, karena ia membicarakan realitas puncak yang mencakup segala sesuatu. Sementara sains partikular yang terdiri dari sains-sains alam, berkaitan dengan wilayah tertentu dan terbatas. 
Antara sains metafisika dengan sains pertikular terdapat sebuah pengetahuan yang disebut dengan kosmologi. Kosmologi yang dimaksud dalam tulisan ini adalah sains yang berhubungan dengan struktur kosmos dan kandungan kualitatifrya. ${ }^{31}$

Menurut Nasr, kosmologi mampu untuk menjadi "alat integrasi konseptual", karena tujuannya adalah untukmengadakan sebuah sains yang memperlihatkan kesaling terkaitan segala sesuanu dan mengadakan hubungan dengan tingkar-tingkat hirarki kosmik satu sama lain, sampai akhinnya mencapai Prinsip Tertinggi. Dengan demikian, ia menjadi sebuah pengetahuan yang memungkinkan terjadinya integrasi keanekaragaman ke dalam keterpaduan. ${ }^{32}$

\section{Modernisme dan Kritik Pascamodernise: Signifikansi Pemikiran Nasr}

Abad modern dimulai dengan revolusi ilmu pengetahuan. Revolusi ilmu pengetahuan ditandai dengan kemenangan rasionalisme dari dogmatisme agama di Barat. ${ }^{33}$ Perpaduan rasionalisme dan empirisme dalam satu paket epistemologi melahirkan apa yang disebut metode ilmiah. Dengan metode ilmiah, kebenaran pengetahuan hanya diukur dengan sudut koherensi dan korespondensi.

Pengetahuan dianggap benar apabila secara logik bersifat koheren (runtut) dengan kebenaran sebelumnya dan didukung oleh fakta empirik (koresponden).

Kepercayaan yang sangat tinggi terhadap metode ilmiah yang demikian tampaknya membawa kesadaran yang kurang atau bahkan tidak apresiatif terhadap pengetahuan yang berada di luar lingkup pengujian mewde ilmiah, termasuk pengetahuan dan nilai-nilai religius. ${ }^{34} \mathrm{M}$ mu betul-betul bersifat sekuler, dan manusiapun hanya diperhitungkan dari sudut biologis dan fisiologis. Hubungan ilmu pengetahuan dengan nilai nilai, terutama yang berasal dari agama, pada tingkat yang ekstrim dianggap bersifat kontradiktif; sekurangkurangnya ilmu pengetahuan terbebas dari nilaidalam arti menyelunth (muncul semboyan : ilmu untukilmu). 
Secara singkat dapat disimpulkan bahwa kerangka berpikir keilmuan modem berusaha melepaskan diri dari dimensispiritual. Kesadaran manusia digiring ke arah yang sekuler. Metode ilmiah yang bebas nilai dan kesadaran manusia yang terlepas dari dimensi spiritual terbukti tidak membawa kebahagiaan dalam kehidupan manusia. Manusia Barat Modern tidak lagi mengetahui tentang makna dan tujuan hidup (meaning and purpose of life). ${ }^{35}$

Bersamaan dengan kritik-kritik itu timbul pula revisi dalam bentuk merelatifkan keabsolutan yang selama ini dinisbahkan kepada metode ilmiah, sekaligus berupaya membuka jalan bagi masuknya nilai-nilai ketuhanan dan dimensi spiritual ke dalam dasar epistemologis, ontologis, dan aksiologis keilmuan. Bahkan ada yang melihat bahwa nilai-nilai yang berdasarkan pada ajaran wahyu (agama) dapat masuk ke dalam proses metodologi keilmuan. Metode ilmiahtidak dapat lagi dipertahankan bersifat netral dalam arti mutlak.

Berbeda dengan kritik modernisme terhadap kerangka berpikir keilmuan dan kesadaran pra-modern, kritik pascamodern terhadap kerangka berpikir keilmuan dan kesadaran manusia lebih merupakan revisi penyempurnaan ketimbang penghancuran. Kritik pascamodern tidak menghilangkan rasionalitas dan tidak mengalihkan perhatian manusia darifenomena material kedunia spiritial, tetapi melengkapi rasionalitas dengan kunci-kunci filosofi yang memuat pandangan dunia dan moralitas keagamaan. ${ }^{36}$

Dari serangkaian uraian di atas, tampak bahwa pemikiran epistemologi Nasr mempunyai signifikansi dengan kesadaran manusia modern atau pascamodern, manusia modern atau pascamodern membutuhkan kesadaran moral dan makna hidup. Nasr menawarkan dalam bentuk formulasi spiritualitas-religius dalam kerangka pemikiran manusia modem. 


\section{Notes}

1. C. Verhaak, Filsafat Ilmu Pengetabuan (Jakarta: Gramedia, 199 I., hal.DX.

2 Ibid, hal, 139.

3. Jujun S. Suriasumantri, Ilmu dalam Perspektif(Jakarta : PT. Gramedia, 1983), hal. 10.

4. Akbar S. Ahmed, Postonodemism and Islam (London-New York: Roudledge, 1992), hal.29.

5. Hanna Djumhana Bastaman, "Dimensi "Spinitualitas" dalam Teori Psikologi" dalam Ulumul Qur'an, Nomor 4, Vol. V, Tahun 1994, hal. 16.

6. Gregory Bateston, Steps to an Ecology ofmind (New York: Paladin, 197 1). hal.463.

7. Ibid

8. Jujun S. Sunasumanni, Filsafat Immu Sebuab Rengantar (Jakaru: Sinar Harapan, 1990), hal 120.

9. Ziaudin Sardar, Rekeyasa Masa Depan Peradaban Muslim (Bandung: Mizan, 1991). Hal. 102.

10. Seyyed Hossein Nasr, Llam an the Plight oj'Modem Man (London Longmans, 1976), hal.21.

11. William C. Chittuk, "Preface", dalam Mehdi Aminazavi and Zailan Morris, The Complete Bibliograft of Seyjed Hossein Nasr from 1958 Though April 1993 (Kuala Lumpur:Islamic Academy of Science of Malaysia, 1994), hal.xiii.

12. Jane 1. Smith, "Seyjed Hossein Nasr", dalam John L. Esposito, The Oxfond Enoydo pedia of the Modern Islamic World (New York-Oxford: Oxford University Press, 1995). hal.230.

13. William C. Citrik, Ibid., hal.xiv.

14. Jane I. smith, Ibid

15. Ira M. Lapidus, A Histony of Islamic Societies (New York: Cambridge University Press, 1989), hal.586-88.

16. Abcurrahman Wahid, "Pengantar" dalam Nasr, Itam dalan Cita dan Fakta (alkarta: Leppenas, 1981), hal. viii-ix.

17. Dagobert D. Reray Dicionary of Ptrilesophy (Newejerey: Adams and Company, 1971). hal.94.

18. Betrend Russel, Histony of Westem Philosophy (Lonson: George Allen \& Uwim, 1945), hal.94.

19. V. Verhaak, op. cit, hal. 163.

20. Nasr, Sains dan Peradaban dalam Islam (Bandung: Pustaka, 1986), hal.74; lihat juga 
Nasr, Knowledge and the Sacred (Edinburg : Edinburg University Press 1981), hal. i. 199.

21. 'Hahut berasal dari kata Huwa yang berarti Dia; Jadi dapat diterjemahkan sebagai quiddity atau Ipseity

22. Nasr, Three Muslim Sages (New York : Caravan Books, 1976), ha]. 111-112.

23. Lihat al-Qur'an : surat 37:3.

24. Nasr, Sains dan Peradaban dalam Islam, loc, cit.

25. Ibid, hal.75.

26. Pada kenyataannya, al-Qur'an dengan tegas menekankan bahwa kesatuan kosmi merupakan bukti yang jelas akan keesaan Tuhan. Lihat Qur'an 21:22.

27. Nasr, Filsafat Ptrennial: Perspektif alternatif untuk studi Agama, Ulumul Qur'an Vol.111. No.3, 1992. hal.86.

28. Penjelasan Nasr tentang intelectus, ia menulis : "the word intellec is used in its original Latin sense as intellectus or the Greek nous, which stands above reason and is able to gain knowledgedirecthy and immediately. Reason is only the reflection upon the minor of fromer mind". Lihat Nasr, Islam and the Plight, op.cit, hal.24.

29. Lihat Nasr, Islamic Science: "Reflextion on Metodology in the Islamic Sciences dalam Harndard Islamious, 1980, bal.3-13. Juga Nasr, An Introduction to Islamic Cosmological Doctrine (London: Themes \& Houdson, 1978).

30. Tentang keragaman madzab intelektual, lihat Nasr, Islamic Life and Thought (Albany : Suny Press, 198 1); Madjid Fakhry, a Histony oflslamic Philosopby. (New York: Columbia University Press, 1983). Mengenai pandangan madzab-madzab itu tentang mecodologi pengetahuan, lihat Nasr, "Intelectuc and Intuition: Their Relationship from Islamic Perspective", dalam S Azam (ed.), Islam and Contemporarv Society (Islamic Council of Europe, 1982).

31. AliMaksum, Tradisionalione Llam dalam Pemikiran Hossein Nasr (Thesis. 1996), belum diterbitkan, hal.168.

32. Nasr, "The Cosmos and the Nature Order", dalam Nasr (ed.). Islamic Spirituality: Foundation Jilid 19 (London: Routledge \& Kegan Paul, 1987), hal.350. I'- F.B. Burhan (ed), Itostnodem Theology (SAn Fransisco: Harper \& Row Publisher, 1989). hal.ix.

34. Lihat Misalnya : Betrand Russel, Religion and Science (Lonson : Oxford University Press, t.th.), hal. 142; T.G. Masaryk, Modem Man and Religion (Westport-Connecticut: Greenwood Press Publisher, 1970), hal.55.

35. Komaruddin Hidayat dan Mohammad Wahyuni Nafis, Agama Masa Depan: Perspektif Filsafat Perennial (Jakarta: Paramadina, 1995), hal.47. 
36. Houston Smith, Posonodernism and world's Religion (Makalah, diampaikan pada Inaugural symposium Islam and the Challenge of Modernity, ISTAC Kuala Lumpur, 1-5 Agustus 1984), hal.9.

\section{Bibliography}

Wahid, Abdurrahman, "Pengantar", dalam S.H. Nasr, Islam dalam Cita dan Fakta Oakarta: Leppenas, 1981).

S. Ahmed, Akbar , Postmodernism and Islam (London-New York: bb Roudledge, 1992).

Maksum, Ali, Tradisionalisme Islam dalam Pemikiran Hossein Nar (Thesis. 1996), belum diterbitkan.

Russel, Betrand, History of Western Philosophy (London: George Allen \& Unwin, 1945). , Religius and Science (London: Oxford University Press, t.th.)

Verhaak, C. , Filsafat Ilmu Pengetabuan (Jakarta: Gramedia, 1991).

D. Runes, Dagobert, Dictionary of Pbilosoptyy (New Jersey: Adams and Company, 1971).

Burhan, F.B. (ed.), Postmodern Theology (San Fransisco: Herper \& Row Publisher 1989).

Bateston, George, Steps to An Ecology of Mind (New York: Paladin, 197 1).

Bastaman, Hanna Djumhana;- "Dimensi "Spiritualitas" dalam Teori Psikologi", JumalUlumul Qur'an, nomor 4, vol. 4, Th. 1994.

Smith,Houston, Postmodennism and World's Religion (Makalah, disampaikan pada Inaugural Symposium Islam and the Challenge of Modernity, ISTAC Kuala Lumpur, 1-5 Agustus, 1984). -

Lapidus, Ira M. A History of Llamic Societies (New York : Canbridge University Press, 1989).

Janel. Smith, "Seyjed Hossein Nasr", dalam John L.Esposito, The Oxford Eragdopedia of the Modern Islamic World (New York-Oxford: Oxford University Press, 1995).

Suriasumantri, Jujun S. ,llmu dalam Perspektif Oakara : Gramedia, 1983). , Filkafat llmu Sebueb Pengantar (Jakarta: sinar Harapan, 1990).

KomanuddinHidayat dan Mohammad Wahtyuni Nafis,Agama Mase Depan: Exspetrif Filsafat Perennial (Jakarta : Paramadina, 1995).

Fakhry, Madjid A Histony of Lslamic Pbilosophy (New York : Columbia University Press, 1983). 
Nasr,Seyyed Hossein, Islam and The Plight of Modem Man (London : Longmans, i. 1976). ., sains dan Peradaban dalam Islam, terj. (Bandung : Pustaka, 1986). , Knowledge and the Sacred (Edinburg: Edinburg University Press, 1981). ,Three Muslim Sages (New York: Coravan Books, 1976). , "Filsafat Perennial: Perspektif altematif untuk studi agama", dalam Jumal Ulumul Qur'an, Vol. 111, No.3 Th. 1992. , Ilamic Science: "Reflecion on Methodology in the Islamic Science", dalam Hammdard Islamicus, 1980). , Islamic Life and Thought (Albany : Sunny Press, 1981) Intelect and Intuition: Their Relationssipfrom Islamic Rerspective, dalamS. Azam(ed), Islam and Contemporary Society (Islamic Council of Europe, 1982). , The Cosmos and the Nature Order", dalam S.H. Nasr (EdI) Islamic Spirituality: Foundation jilid 19 (London Routiedge \& Kegan Paulk, 1987).

Masaryk,T G., Modem Man and Religion (Westport-Connecticute: Greenwood Press Publisher, 1970).

Chittik, William C. "Preface", dalam Mehdi Aminrazavi and Zailan Morris, The Complete Bibliografi of Seyyed Hossein Nasr from 1958 Though april 1993 (Kuala Lumpur: Islamic Academy of Science of Malaysia, 1994).

Sardar, Ziauddin, Rekayasa Masa Depan Peradaban Muslim (Bandung Mizan, 1991). 